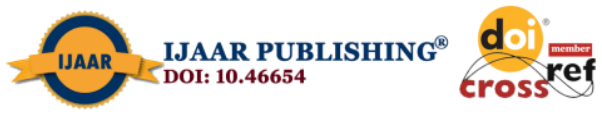

International Journal of Advanced Academic Research (Social and Management Sciences) | ISSN: 2488-9849

Vol. 6, Issue 12 (December, 2020) |www.ijaar.org

Journal DOI: 10.46654/ij.24889849

Article DOI: 10.46654/ij.24889849.s61229

\title{
ECONOMIC IMPACT OF ADVANCED RAILWAY TECHNOLOGY IN NIGERIA
}

\author{
Mr. Pullah Ebipre and Dr. Micheal Ayibanua Amaegberi \\ Department of Economics \\ Ignatius Ajuru University of Education, Iwofe \\ Port Harcourt, Nigeria
}

\begin{abstract}
Railways network system has created billions of dollars in different economies around the world. The railway system has served as a source of revenue for many advanced nations. This study tends to look at the economic benefit of railway system in Nigeria. Two research questions were used for the study. The survey research design was used in the study. The researchers used a total of 740 individuals including business operators for the study. The study used random sampling technique to select 240 experts which represents $10 \%$ of the population used for the study. The researcher developed an instrument titled "Economic Impact of Advanced Railway Technology" (EIART). The instrument is a questionnaire item consisting of 2 items. The data obtained from the study was computed using percentages. Findings from research question 1 , table 1 revealed that 47\% of individuals to a very high extent agreed that advanced railway system can encourage economic growth in Nigeria. Also, $47 \%$ of individuals to a high extent agreed that advanced railway system can encourage economic growth in Nigeria. 6\% of individuals to a moderate extent agreed that advanced railway system can encourage economic growth in Nigeria. Research question 2, table 2 revealed that $8 \%$ of individuals to a very high extent agreed that advanced railway technology will create jobs and other business opportunities in Nigeria. Also, 46\% of individuals to a high extent agreed that advanced railway technology will create jobs and other business opportunities in Nigeria. 39\% of individuals to a moderate extent agreed that advanced railway technology will create jobs and other business opportunities in Nigeria. Finally, 7\% of individuals strongly disagree that advanced railway technology will create jobs and other business opportunities in Nigeria. Finally it was recommended that government should advance its projects towards installing advanced railway system to encourage more industrialization and movement of goods and services to the benefit of the nation.
\end{abstract}

Keywords: Economic Impact and Advance Railway Technology 
Journal DOI: 10.46654/ij.24889849

\section{Introduction}

\section{Railway Technology in Nigeria}

The use of railway technology is not new in Nigeria. During the colonial era in Nigeria, railway system has been widely patronized as a common means of transportation. The railway technology that usually makes use of small track ways with metal structure attached to it can travel on thousands of miles with large loads and passengers. An efficient transport system, especially railway transport, plays a significant role in any economy through the movement of people and goods from one destination to the other safely. In essence, an effective and efficient transport system aids commerce and helps economic activities of any country. Rail transport therefore plays a significant role in commerce and economic activities of the Nigerian economy due to its ability to haul large volumes of cargo and carry large numbers of passengers at a very low cost. Nigeria is endowed with a total land mass of 351,649 sq. miles $(910,771 \mathrm{sq} . \mathrm{km})$ with a total population of about 170 million (Sanusi, 2014).

The railway in Nigeria was originally a government department in 1898 which later metamorphosed to NRC as created by the Act of 1955 (amended by 1990 Act). NRC was therefore established to carry on its activities among others including the movement of passengers and haulage of freight in a way that offers full scale transportation services, ensure value for money, adhere to the corporate goals, meet the expectations of passengers, ensure safety of operation with maximum efficiency, meeting the social responsibility of the corporation in the manner that meets and satisfies the needs of the rail users, industry, the general public and other stakeholders (Adesanya, 2010). The establishment of the corporation took place in October 1955, by an Act of Parliament which also granted the corporation a monopoly power. In total, at the official inauguration, Nigeria had a 3505 kilometer narrow gauge single-track railway network system (Abubakar, 2006; Odeleye, 2010). As discussed earlier, the perceived benefits of efficiency and a cheaper cost of transportation of farm produce to the European market acted as the motivator for early construction of the rail lines in Nigeria by the colonial administration. Construction of the railway lines started in 1892 and went on until 1965, however, this early construction was without foresight and consideration of the full potential social benefits of railway system to the community. Hence in expressing an opinion, the pursuit of cheaper and modest investments in rail transport could also mean that geographical terrain that was deemed too costly for construction was avoided. This probably explains why deep cuttings, high embankments, long bridge spans, tunnels and viaducts which would have potentially increased the cost of construction were avoided. Foresight could have however dictated that the increased cost of construction could have also off-set the benefits of service efficiency, effectiveness and the connection of major towns and villages across Nigeria. The line, therefore, runs diagonally, from South-West to NorthEast and from South-East to North-West with junctions in Kafanchan and Kaduna respectively (Okanlawon, 2006). The short-sighted construction created a rail system that was not favourable for the movement of traffic intended for internal eastwest developments leaving vast areas of the country unconnected. These areas remained comparatively under-developed until the construction of roads and national highways was started after the country became independent in 1960. In addition, travel times were also elongated and travel speed was slowed to a maximum of $65 \mathrm{~km} / \mathrm{h}$ due to the steep curves, poor track equipment, sharp bends and the narrow gauge of the rail lines. Although there is over 
$100,000 \mathrm{~km}$ of national highways, there is a dire need for an extension of the present railway system, construction of new lines serving specific industrial project areas and better integration of the country by providing a cheaper means of transportation (Oni, 2010; Ademiluyi and Dina, 2011). Ademiluyi and Dina, (2011) observed that "despite all these inherent defects, the rail mode had, until the 1960s, enjoyed a real monopoly in the transport sector." It was further noted that, by the middle of the 1970 s, the quality of rail service began a fast decline. The apparent decline of the corporation's services observed at the time still persists today as a result of inadequate funding and near neglect by successive administrations of the country (Ademiluyi and Dina, 2011).

Modern railway systems are faster and use more beautiful facilities. A recent and more sophisticated train technology is the bullet train. Most trains have luxurious apartments, facilities that are more comforting to passengers. Most of these systems create lots of job opportunities, huge financial returns and lots of other privileges. If this technology is applied in Nigeria, it will create more opportunities and generate revenue for the country. Economically, there is a tendency and prediction for rise in GDP and employment rate. However, the study tends to look at the economic impact of advanced railway technology in Nigeria.

\section{Purpose of the Study}

The study looked at the economic impact of advanced railway technology in Nigeria. Specifically, the study tends to:

1. Find out the extent to which advanced railway technology can boost economic growth in Nigeria.

2. Find out the extent to which advanced railway technology can create jobs and other business opportunities.

\section{Research Questions}

The following research questions serve as a guide for the study:

1. What is the extent to which advanced railway technology can boost economic growth in Nigeria?

2. What is the extent to which advanced railway technology will create jobs and other business opportunities in Nigeria?

\section{Methodology}

The survey research design was used in the study. The researchers used a total of 740 individuals including business operators for the study. The study used random sampling technique to select 240 experts which represent $10 \%$ of the population used for the study. The researcher developed an instrument titled "Economic Impact of Advanced Railway Technology" (EIART). The instrument is a questionnaire item consisting of 2 items. The data obtained from the study was computed using percentages. 
Journal DOI: 10.46654/ij.24889849

Article DOI: 10.46654/ij.24889849.s61229

\section{Data Analysis}

\section{Research Question 1}

What is the extent to which advanced railway technology can boost economic growth in Nigeria?

Table 1: Extent to which advanced railway technology can boost economic growth in Nigeria.

\begin{tabular}{|l|l|l|l|l|l|l|}
\hline S/NO & Items & $\begin{array}{l}\text { Very High } \\
\text { Extent }\end{array}$ & $\begin{array}{l}\text { High } \\
\text { Extent }\end{array}$ & $\begin{array}{l}\text { Moderate } \\
\text { Extent }\end{array}$ & Disagree & $\begin{array}{l}\text { Strongly } \\
\text { Disagree }\end{array}$ \\
\hline 1 & $\begin{array}{l}\text { Extent to which } \\
\text { advanced railway } \\
\text { technology can boost } \\
\text { economic growth in } \\
\text { Nigeria }\end{array}$ & & $47 \%$ & $6 \%$ & $0 \%$ & $0 \%$ \\
\hline
\end{tabular}

Table 1 revealed that $47 \%$ of individuals to a very high extent agreed that advanced railway system can encourage economic growth in Nigeria. Also, $47 \%$ of individuals to a high extent agreed that advanced railway system can encourage economic growth in Nigeria. 6\% of individuals to a moderate extent agreed that advanced railway system can encourage economic growth in Nigeria.

\section{Research Question 2}

What is the extent to which advanced railway technology will create jobs and other business opportunities in Nigeria?

Table 2: Extent to which advanced railway technology will create jobs and other business opportunities in Nigeria.

\begin{tabular}{|l|l|l|l|l|l|l|}
\hline S/NO & Items & $\begin{array}{l}\text { Very High } \\
\text { Extent }\end{array}$ & $\begin{array}{l}\text { High } \\
\text { Extent }\end{array}$ & $\begin{array}{l}\text { Moderate } \\
\text { Extent }\end{array}$ & Disagree & $\begin{array}{l}\text { Strongly } \\
\text { Disagree }\end{array}$ \\
\hline 1 & $\begin{array}{l}\text { Extent to which } \\
\text { advanced railway } \\
\text { technology will create } \\
\text { jobs and other business } \\
\text { opportunities in } \\
\text { Nigeria }\end{array}$ & $8 \%$ & $46 \%$ & $39 \%$ & $0 \%$ & $7 \%$ \\
\hline
\end{tabular}

Table 2 revealed that $8 \%$ of individuals to a very high extent agreed that advanced railway technology will create jobs and other business opportunities in Nigeria. Also, $46 \%$ of individuals to a high extent agreed that advanced railway technology will create jobs and other business opportunities in Nigeria. $39 \%$ of individuals to a moderate extent agreed that advanced railway technology will create jobs and other business opportunities in Nigeria. Finally, $7 \%$ of individuals strongly disagreed that advanced railway technology will create jobs and other business opportunities in Nigeria. 


\section{Discussion}

The findings of the study showed that to a large extent the introduction of advanced railway system will improve the economic activities in Nigeria. This is in line with the view of Wakeham, (2010) that the role of logistics to supply services or products to customers at the right time, in the right quantity, in the right quality, at the right cost and at the right place can be achieved by railway system.

Further, the findings also revealed that railway system can create job and business opportunities. This is in line with the view of Handfield et al. (2009) that assert that cost, speed, reliability, capability and accessibility are also some of the key considerations in modal choice.

\section{Recommendations}

Finally it was recommended that government should advance its projects towards installing advanced railway system to encourage more industrialization and movement of goods and services to the benefit of the nation. 


\section{References}

Abioye O (2016). Privatization of the Nigerian Railway Corporation: An evaluation of critical choices. PhD thesis, submitted to Cardiff Metropolitan University. Repository.cardiffmet.ac.uk

Abubakar AA (2006). Nigerian Railways: Past, present and future perspectives. Rail News, 4(6): 4

Ademiluyi IA, Dina OA (2011). The Millennium Development Goals and the Sustainable Future for Nigeria's Urban Environment: A Railway Strategy. J Hum Ecol, 33(3): 203209

Adesanya A (2010). Bringing the Nigerian Railways Back on track - challenges and options. Paper presented at monthly NISER seminar series, held at the NISER conference room, November.

Akwara AF, Udaw JE, Ezirim GE (2014). Adapting Colonial Legacy to Modernism: A focus on Rail Transport Development in Nigeria. Mediterranean Journal of Social Sciences. Vol 5. No 6. April. ISSN 20392117.

Handfield, R. B., Monczka, R. M., Giunipero, L. C. \& Patterson, J. L., 2009. Sourcing and supply chain management. 4th ed. Canada: Cengage Learning.

Odeleye JA (2000). Public-Private Participation to rescue railway development in Nigeria. Japan Railway and Transport Review 23, March.

Odeleye JA (2010). Politics of Rail Transport Development in Developing Countries: Case of Nigeria. 12th WCTR, July. Lisbon, Portugal.

Okanlawon KR (2006). “Towards Enhancement of Light Rail System in Efficient Transportation of commuters in Lagos State" in Journal of Social Policy and Society, Volume 1, Number 1 , pp. 22 - 27.

Oni OAG (2010). Tackling Road Traffic Congestion in a Developing Country - A Contemporary Approach. Journal of Applied Sciences Research, 6(5): 529-542. INSInet Publication.

Sanusi LS (2014).Overcoming the fear of vested interests: SanusiLamido CBN Governor. Http://connectnigeria.com/articles/2014/01/14/tedxmaitama-overcoming-the-fear-ofvested-interests-sanusi-lamido-cbngovernor/?wpmp_tp $=3$

Wakeham, M. 2010. Transportation. 2nd ed. Cape Town: International Colleges Group 